Check for updates

Cite this: Chem. Sci., 2019, 10, 5156

๑ All publication charges for this article have been paid for by the Royal Society of Chemistry

Received 31st January 2019

Accepted 15th April 2019

DOI: $10.1039 / \mathrm{c} 9 \mathrm{sc00568d}$

rsc.li/chemical-science

\section{Synthesis of $\alpha$-heterosubstituted ketones through sulfur mediated difunctionalization of internal alkynes $\uparrow$}

\author{
Zhong Zhang, (D) Yuzheng Luo, Hongguang Du, (D)* Jiaxi Xu (D) * and Pingfan Li (D) *
}

Synthesis of $\alpha$-heterosubstituted ketones was achieved through sulfur mediated difunctionalization of internal alkynes in one pot. The reaction design involves: phenyl substituted internal alkyne attacking triflic anhydride activated diphenyl sulfoxide to give a sulfonium vinyl triflate intermediate, hydrolysis to give an $\alpha$-sulfonium ketone, and then substitution with various nucleophiles. This method provides a unified route to access $\alpha$-amino ketones, $\alpha$-acyloxy ketones, $\alpha$-thio ketones, $\alpha$-halo ketones, $\alpha$ hydroxy ketones, and related heterocyclic structures, in a rapid fashion.

\section{Introduction}

Ketones bearing $\alpha$-heteroatom substituents constitute a class of compounds with significant synthetic interest. ${ }^{1}$ Besides being important building blocks for more complex target structures, many drugs and biologically active molecules contain $\alpha$-amino or $\alpha$-hydroxy ketone moieties. For example, they are key substructures of bupropion $^{2}$ and brephedron, ${ }^{3}$ which are used in the clinical treatment of psychological disorders.

The most widely used method for synthesizing these compounds include: electrophilic $\alpha$-halogenation/ $\alpha$-oxidation/ $\alpha$-amination of ketones or corresponding enolates, ${ }^{4}$ as well as nucleophilic substitution of $\alpha$-bromo ketones with oxygen, chalcogen, or nitrogen nucleophiles. ${ }^{5}$ Oxidative difunctionalization of alkenes is another attractive route to give $\alpha$-heterosubstituted ketones. ${ }^{6}$ Recently, difunctionalization of alkynes also emerged as an alternative route to access such structural motifs. ${ }^{7}$ Murakami's group ${ }^{8}$ developed a copper/rhodium catalyzed two-step reaction sequence for converting terminal alkynes to $\alpha$-amino ketones via triazole intermediates (Scheme 1a). Liang's group ${ }^{9}$ reported the synthesis of $\alpha$-succinimide/phthalimide substituted ketones though bromohydration of alkynes and subsequent substitution (Scheme 1b). Hou et al. reported the conversion of terminal alkynes to $\alpha$-acetoxy ketones by using $\mathrm{PhI}(\mathrm{OAc})_{2}$ as an oxidant (Scheme 1c). ${ }^{10} \mathrm{Zhang}$ et al. developed a gold catalyzed reaction for converting terminal alkynes to $\alpha$-acyloxy ketones (Scheme 1d). ${ }^{11}$

State Key Laboratory of Chemical Resource Engineering, Department of Organic Chemistry, Faculty of Science, Beijing University of Chemical Technology, Beijing 100029, China.E-mail: dhg@mail.buct.edu.cn; jxxu@mail.buct.edu.cn; lipf@mail. buct.edu.cn

† Electronic supplementary information (ESI) available. See DOI: $10.1039 / \mathrm{c} 9 \mathrm{sc} 00568 \mathrm{~d}$

On the other hand, to the best of our knowledge, a general one-pot method for converting alkynes to different types of $\alpha$-heterosubstituted ketone products has not been reported. ${ }^{12}$ It should be noted that the nitroso aldol reaction of ketones or

a)

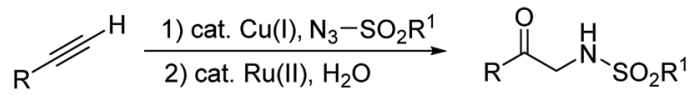

b)

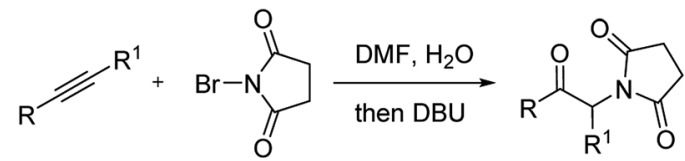

c)

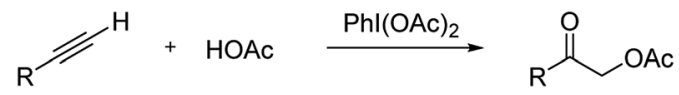

d)

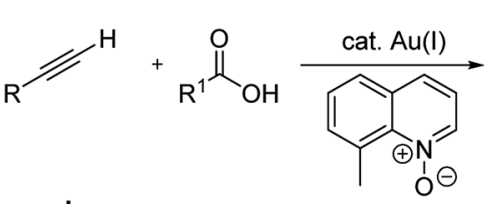<smiles>[R]C(=O)COC([R])=O</smiles>

This work:

e) $\mathrm{R}$<smiles>[R]C#Cc1ccccc1</smiles>

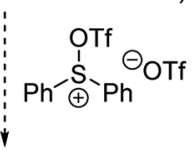

) add nucleophile in one pot

$$
\text { (1) }
$$

$$
\text { (1) }
$$


aldehydes did provide a way to introduce either nitrogen or oxygen atom at the $\alpha$-position of carbonyls under complementary organocatalyzed or acid catalyzed conditions. ${ }^{4 a, 13}$ But extra steps were usually required to cleave the resulting $\mathrm{N}-\mathrm{O}$ bond of such nitroso aldol products. MacMillan's group ${ }^{\mathbf{1 4}}$ also developed an efficient $\mathrm{CuBr}_{2}$ catalyzed coupling of $\alpha$-carbonyls with dialkyl amines. However, extension of such a catalytic system to other nucleophiles has not been reported. Recently, Hartwig's group reported a general solution for enantioselective $\alpha$-functionalization of ketones via an iridium catalyzed reaction of allylic carbonates containing silyl enol ethers as masked ketones. ${ }^{15}$ Herein, we describe a one-pot, transition-metal-free method for the synthesis of $\alpha$-heterosubstituted ketones through sulfur mediated difunctionalization of internal alkynes (Scheme 1e).

In connection with our recent interest in sulfur mediated $\mathrm{C}-\mathrm{H}$ functionalization of alkenes ${ }^{\mathbf{1 6}}$ and alkynes, ${ }^{17}$ we are interested in the reactivity of sulfonium vinyl triflate intermediate $\mathbf{A}$ generated through alkyne attack of triflic anhydride activated diphenyl sulfoxide (see Scheme 1e). ${ }^{17 a, 18}$ We reasoned that if hydrolysis of $\mathbf{A}$ could give $\alpha$-sulfonium ketone $\mathbf{B}$, subsequent substitution with various nucleophiles in one pot would then afford different types of $\alpha$-heterosubstituted ketones in a rapid and unified fashion.

\section{Results and discussion}

We chose 1-phenyl-1-butyne (1a) and aniline (2a) as our model substrates to find the optimal reaction conditions for the synthesis of $\alpha$-amino ketone 3aa (Table 1). For the first step, i.e. alkyne (1a) attack of triflic anhydride activated diphenyl sulfoxide, similar conditions were adopted to our previous studies on a sulfur mediated propargylic $\mathrm{C}-\mathrm{H}$ alkylation reaction of alkynes. ${ }^{17 a}$ We soon realized that the key to success of this onepot reaction design was the optimal aqueous hydrolysis and buffer conditions for the conversion of sulfonium vinyl triflate intermediate $\mathbf{A}$ to $\alpha$-sulfonium ketone $\mathbf{B}$. Hydrolysis of $\mathbf{A}$ seems to proceed best with basic aqueous sodium hydroxide, presumably through an addition/elimination pathway. However, with an excessive amount of sodium hydroxide, $\alpha$ sulfonium ketone $\mathbf{B}$ would be converted to the corresponding carbonyl stabilized sulfur ylide $\mathbf{C}$, which could not be used as the electrophile in our subsequent nucleophilic substitution reaction with aniline (2a). And thus, we have to acidify the reaction mixture appropriately to suppress the deprotonation of $\mathbf{B}$, but not to acidify it too much as to protonate our nucleophilic amine base $2 \mathbf{a}$. Eventually, we found that the use of 3 equivalents of sodium hydroxide and 20 equivalents of water, followed by addition of 2 equivalents of sodium dihydrogen phosphate and 1.5 eq. (2a), gave $72 \%$ yield of product 3aa (Table 1, entry 1 ). The results of deviation from the optimized reaction conditions are shown in Table 1 (entries 2-7). ${ }^{19}$ First, the amounts of sodium hydroxide and sodium dihydrogen phosphate were varied (entries 2-4). Then, tetramethylammonium hydroxide pentahydrate was used as the base (entry 5), and triflic acid (TfOH) or $p$-toluenesulfonic acid (PTSA) was used as the acid in step 2 (entries 6-7). None of these deviations afforded better yields than our standard conditions.

With the optimized reaction conditions in hand, the internal alkyne substrate scope was examined (Table 2). For phenyl substituted alkynes $\mathbf{1 b}, \mathbf{1 f}, \mathbf{1 g}$, and $\mathbf{1 h}$, corresponding $\alpha$-amino ketone products $\mathbf{3 b a}, \mathbf{3 f a}$, 3ga, and $\mathbf{3 h a}$ were obtained in good yields. Olefin containing product 3da was obtained in 52\% yield, showcasing that the reactivity of phenyl substituted internal alkynes toward triflic anhydride activated sulfoxide reagents was higher than that of the terminal alkene moiety. Phenyl alkyne substrates bearing alkyl or halide $(-\mathrm{F},-\mathrm{Cl}$, and -Br) substituents all afforded products (3ca, 3la, 3ja, 3ka, 3na, 3oa, 3pa and 3qa) in good yields. When an electron-withdrawing acyl group was attached to the phenyl alkyne, a lower yield for product 3ma was observed, and we recovered a significant amount of alkyne substrate $\mathbf{1 m}$. The yield of product 3ra decreased to $21 \%$ when using alkyne $1 \mathrm{r}$ bearing a strongly electron-withdrawing cyano group. For methoxy substituted

Table 1 Optimization of reaction conditions ${ }^{a}$

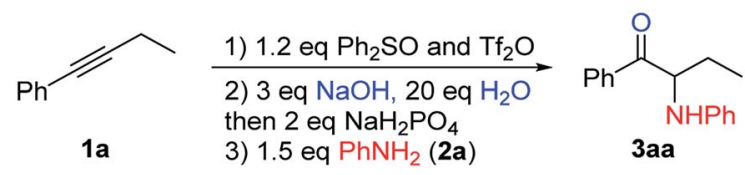

\begin{tabular}{lll}
\hline Entry & Deviation from standard conditions & Yield/\% ${ }^{b}$ \\
\hline 1 & None & 72 \\
2 & Using 5 eq. of $\mathrm{NaOH}, 4$ eq. of $\mathrm{NaH}_{2} \mathrm{PO}_{4}$ in step 2 & 50 \\
3 & Using 1.5 eq. of $\mathrm{NaH}_{2} \mathrm{PO}_{4}$ in step 2 & 62 \\
4 & Using 2.5 eq. of $\mathrm{NaH}_{2} \mathrm{PO}_{4}$ in step 2 & 71 \\
5 & Using 3 eq. of $\mathrm{Me}_{4} \mathrm{NOH}_{5} \mathrm{H}_{2} \mathrm{O}$ instead of $\mathrm{NaOH}$ and $\mathrm{H}_{2} \mathrm{O}$ in step 2 & 49 \\
6 & Using TfOH instead of $\mathrm{NaH}_{2} \mathrm{PO}_{4}$ in step 2 & 63 \\
7 & Using PTSA instead of $\mathrm{NaH}_{2} \mathrm{PO}_{4}$ in step 2 & 63
\end{tabular}

${ }^{a}$ Standard conditions A: a solution of $1 \mathrm{a}(0.4 \mathrm{mmol})$ and $\mathrm{Ph}_{2} \mathrm{SO}(0.48 \mathrm{mmol})$ in $2 \mathrm{~mL}$ of $\mathrm{CH}_{2} \mathrm{Cl}_{2}$ was treated with $\mathrm{Tf}_{2} \mathrm{O}(0.48 \mathrm{mmol})$ at $-78^{\circ} \mathrm{C}$, warmed up to $0{ }^{\circ} \mathrm{C}, \mathrm{NaOH}(1.2 \mathrm{mmol})$ and $\mathrm{H}_{2} \mathrm{O}(8 \mathrm{mmol})$ were added, and stirred at $40^{\circ} \mathrm{C}$ for $12 \mathrm{~h}$. Then, $\mathrm{NaH}_{2} \mathrm{PO}_{4}(0.8 \mathrm{mmol})$ and $2 \mathrm{a}(0.6 \mathrm{mmol})$ were added to the reaction mixture and stirred at $40{ }^{\circ} \mathrm{C}$ for $12 \mathrm{~h}$ before work-up and purification. ${ }^{b}$ Isolated yield after column chromatography. 
Table 2 Scope of alkynes $1^{a b}$
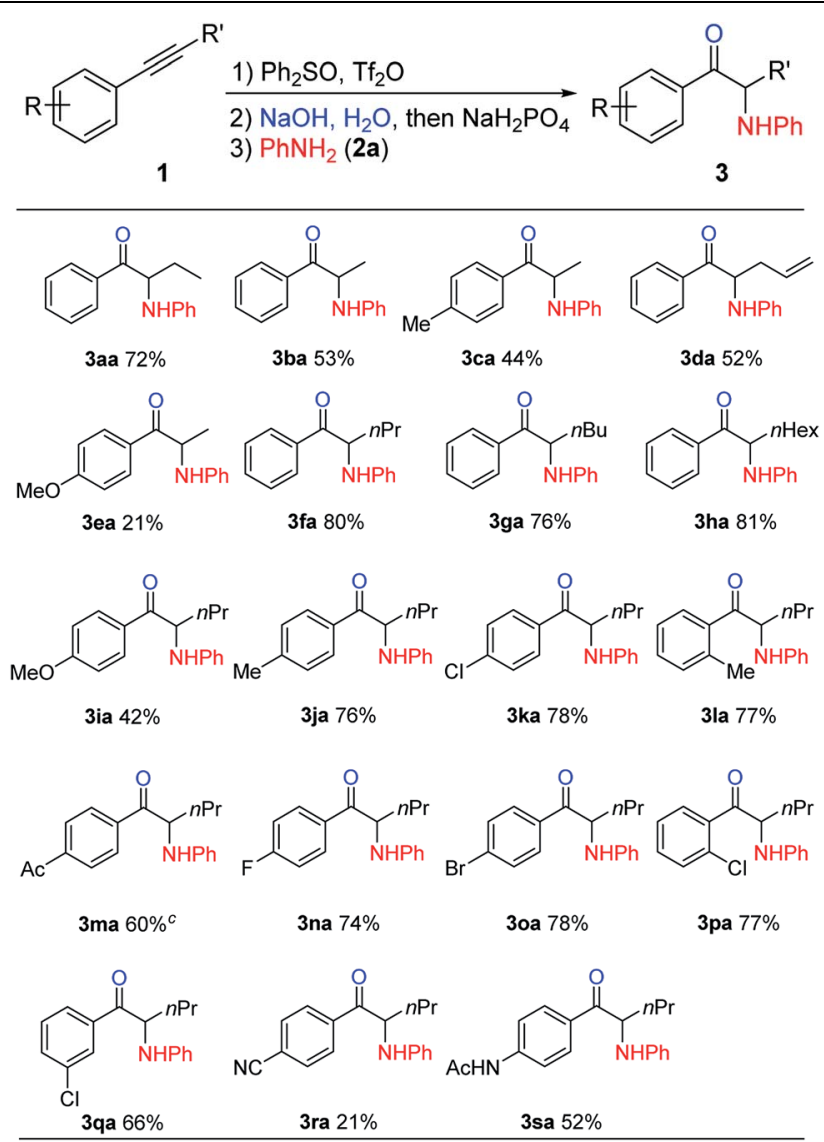

${ }^{a}$ Standard conditions A: (1) $1(0.4 \mathrm{mmol}), \mathrm{Ph}_{2} \mathrm{SO}(0.48 \mathrm{mmol})$, and $\mathrm{Tf}_{2} \mathrm{O}$ (0.48 mmol); (2) NaOH (1.2 mmol), $\mathrm{H}_{2} \mathrm{O}(8 \mathrm{mmol})$, and $\mathrm{NaH}_{2} \mathrm{PO}_{4}(0.8$ mmol); (3) 2a $(0.6 \mathrm{mmol}) .{ }^{b}$ Isolated yield. ${ }^{c} 2$ eq. of $\mathrm{Ph}_{2} \mathrm{SO}$ and $\mathrm{Tf}_{2} \mathrm{O}$ was added in step 1 .

phenyl alkynes 1e and 1i, their reactions with triflic anhydride activated sulfoxide reagents could proceed completely, but it seems that the hydrolysis step was slower, which led to decreased yields for products 3ea and 3ia. For the same reason, substrate 1s gave the product 3sa in a lower yield of $52 \%$. Using terminal alkynes as substrates could not afford this type of product, but would give alkynyl diphenyl sulfonium salts instead. ${ }^{18 h}$ When dialkyl or alkyl silyl substituted alkynes were used, propargylic $\mathrm{C}-\mathrm{H}$ arylation type products were obtained as previously reported by Procter et al. under similar reaction conditions. ${ }^{18 j}$

We then examined the electronic and steric effects of various arylamine nucleophiles on the reaction with alkyne 1a (Table 3). To our delight, amines having both electron-donating and electron-withdrawing groups, as well as having increased steric hindrance at the ortho positions, all reacted smoothly to afford the desired products (from 3ab to 3av) in good to moderate yields. Even with sterically very hindered 2,6-diisopropylphenylamine 2p, the desired product 3ap was still obtained in 54\% yield. Secondary amines $2 \mathbf{u}$ and $2 \mathbf{v}$ could also afford the corresponding $\alpha$-amino ketones 3 au and 3av in $63 \%$ and $55 \%$ yields, respectively.

Table 3 Scope of aryl amine nucleophiles $2^{a b}$

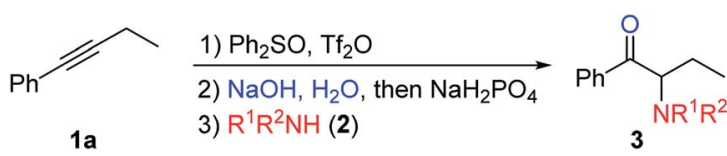

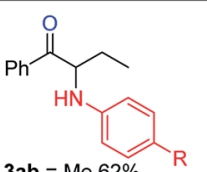

$3 \mathrm{ab}=\mathrm{Me} 62 \%$ $3 \mathrm{ac}=\mathrm{Et} \quad 67 \%$ $3 \mathrm{ad}=\mathrm{Cl} 73 \%$ 3ae $=\mathrm{F} \quad 69 \%$ 3 ag $=1 \quad 75 \%$ $3 \mathrm{ah}=t \mathrm{Bu} 53 \%$<smiles>CCC(Nc1ccc(Cl)cc1)C(=O)c1ccccc1</smiles><smiles>CCC(Nc1c(C(C)C)cccc1C(CC)C(=O)C(CC)Nc1cc(OC)c(OC)c(OC)c1)C(=O)c1ccccc1</smiles><smiles>CCC(Nc1c(C)cc(C)cc1C)C(=O)c1ccccc1</smiles><smiles>CCC(Nc1ccc2ccccc2c1)C(=O)c1ccccc1</smiles>
3ap $54 \%$ 3aq $71 \%$

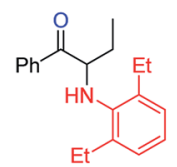

3ai $=$ Me $79 \%$ 3aj = F $61 \%$ 3ak $=\mathrm{Cl} 58 \%$

$3 \mathrm{al}=\mathrm{Me} 53 \%$ $3 \mathrm{am}=\mathrm{Cl} 72 \%$

3an $47 \%$
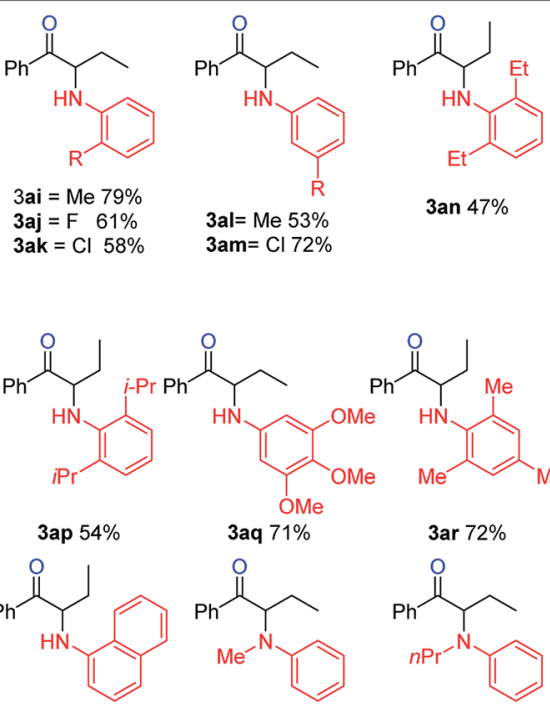

3as $66 \%$

3at $72 \%$

3au $63 \%$

3av $55 \%$

${ }^{a}$ Standard conditions A: (1) $1 \mathrm{a}(0.4 \mathrm{mmol}), \mathrm{Ph}_{2} \mathrm{SO}(0.48 \mathrm{mmol})$, and $\mathrm{Tf}_{2} \mathrm{O}$ $(0.48 \mathrm{mmol}) ;(2) \mathrm{NaOH}(1.2 \mathrm{mmol}), \mathrm{H}_{2} \mathrm{O}(8 \mathrm{mmol})$, and $\mathrm{NaH}_{2} \mathrm{PO}_{4}(0.8$ mmol); (3) 2 (0.6 mmol). ${ }^{b}$ Isolated yield.

We then turned our attention to the preparation of $\alpha$-acyloxy ketones. It is reasoned that carboxylic acid substrates could act not only as nucleophiles, but also as acidic additives to replace the use of sodium dihydrogen phosphate to protonate the initially formed sulfur ylide during the hydrolysis step, and give the desired $\alpha$-sulfonium ketone intermediate. Under further optimized reaction conditions, various carboxylic acids reacted nicely to give $\alpha$-acyloxy ketone products in good yields (Table 4 ). In general, saturated carboxylic acids gave higher yields (5aa5an), while alkenyl, aryl and hetero-aryl substituted carboxylic acids gave lower yields (5ao-5at).

This reaction could also be applied with other nucleophiles (Table 5). A number of thiophenols gave good yields (7aa-7ad). Other sulfur, nitrogen, or halogen based nucleophiles, such as 2-mercaptopyridine $(\mathbf{6 e})$, potassium thioacetate $(\mathbf{6 f})$, potassium O-ethyl carbonodithioate $(\mathbf{6 g})$, sodium azide (6i), potassium thiocyanate $(\mathbf{6 j})$, potassium iodide $(\mathbf{6 k})$ and potassium bromide (61), all gave the desired products (7ae-7al) in good yields. Besides, $\alpha$-hydroxyl ketone 7am could also be obtained in $64 \%$ yield in the same fashion by using tetrabutylammonium hydroxide $(\mathbf{6 m})$ as both the base and nucleophile. Compared with the previous results obtained with sodium hydroxide or tetramethylammonium hydroxide (Table 1 , entry 5 ), the better phase-transfer nature of $\mathbf{6 m}$ seems to be the key factor for the successful formation of 7am.

By using appropriate ambident nucleophiles, a number of interesting heterocyclic structures can be prepared, since the 
Table 4 Scope of carboxylic acid nucleophiles $4^{a}$

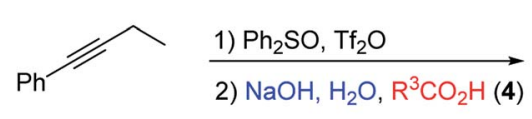

$1 a$<smiles>CCC(OC(C)=O)C(=O)c1ccccc1</smiles>

5aa $91 \%^{\mathrm{C}}$

5 ae $65 \%$<smiles>CCC(OC(=O)C(C)(C)C)C(=O)c1ccccc1</smiles>

5ai $61 \%$<smiles>CCC(OC(=O)C(C)Cl)C(=O)c1ccccc1</smiles>

5am $72 \%$

5aq $45 \%$<smiles>CCC(=O)OC(CC)C(=O)c1ccccc1</smiles>

5ab $75 \%$<smiles>CCC(OC(=O)Cc1ccccc1)C(=O)c1ccccc1</smiles>

5af $93 \%$<smiles>CCC(OC(=O)COc1ccccc1)C(=O)c1ccccc1</smiles>

5aj $54 \%$<smiles>CCC(OC(=O)C(C)Br)C(=O)c1ccccc1</smiles>

5an 69\%<smiles>CCC(OC(=O)c1ccccc1)C(=O)c1ccccc1</smiles>

5ar $48 \%^{b}$<smiles>CCC(OC(=O)C(C)C)C(=O)c1ccccc1</smiles><smiles>CCC(OC(=O)C[AlH2])C(=O)c1ccccc1</smiles>

5ag $72 \%$<smiles>CCC(OC(=O)CCl)C(=O)c1ccccc1</smiles><smiles>C=CC(=O)OC(CC)C(=O)c1ccccc1</smiles>

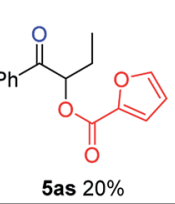<smiles>CCC(OC(=O)C(=O)NC)C(=O)c1ccccc1</smiles><smiles>CCC(OC(=O)[GeH2])C(=O)c1ccccc1</smiles><smiles>CCC(OC(=O)CCCc1ccccc1)C(=O)c1ccccc1</smiles><smiles>CCC(OC(=O)C(C)c1ccccc1)C(=O)c1ccccc1</smiles>

5ah $81 \%$<smiles>CCC(OC(=O)Cc1ccccc1)C(=O)c1ccccc1</smiles>

5al $72 \%$<smiles>CCC(OC(=O)/C=C/c1ccccc1)C(=O)c1ccccc1</smiles>

5ap 39\%

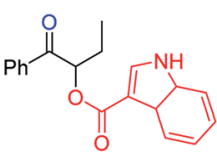

5at $23 \%$

${ }^{a}$ Standard conditions B: (1) $1 \mathrm{a}(0.4 \mathrm{mmol}), \mathrm{Ph}_{2} \mathrm{SO}(0.48 \mathrm{mmol})$, and $\mathrm{Tf}_{2} \mathrm{O}(0.48 \mathrm{mmol}) ;(2) \mathrm{NaOH}(2 \mathrm{mmol}), \mathrm{H}_{2} \mathrm{O}(6 \mathrm{mmol})$, and $4(2$ mmol). ${ }^{b}$ Isolated yield. ${ }^{c}$ Using $\mathrm{RCO}_{2} \mathrm{M}(2 \mathrm{mmol})$ instead of $\mathrm{NaOH}$ and $\mathrm{RCO}_{2} \mathrm{H}$.

initially formed $\alpha$-hetero substituted ketones could undergo intramolecular condensation reactions (Table 6$).^{20}$ When thiourea $\mathbf{8 a}$ and phenylthiourea $\mathbf{8 b}$ were used as nucleophiles, 2aminothiazoles 9aa and 9ab were afforded in 64\% and $82 \%$ yields, respectively. Similarly, when thioamides $\mathbf{8 c}$ and $\mathbf{8 d}$ were used, thiazole products 9ac and 9ad were obtained in 64\% and $58 \%$ yields, respectively. 2-Aminopyridine 8 e gave 3-ethyl-2phenylimidazo[1,2-a]pyridine 9ae in 31\% yield. When orthodiaminobenzene $\mathbf{8 f}$ was used as the nucleophile, the initially formed product was easily oxidized and hard to purify. So we added 3 equivalents of 2,3-dichloro-5,6-dicyano-1,4benzoquinone (DDQ) in one pot after step 3 to give quinoxaline $\mathbf{9 a f}$ in $75 \%$ yield. Similarly, 2-aminothiophenol $\mathbf{8 g}$ gave product 9ag in $75 \%$ yield.

Our proposed reaction pathway is supported by the isolation and reactivity study of potential reaction intermediates (Scheme 2). When alkyne 1a was treated with triflic anhydride activated diphenyl sulfoxide, we could isolate the sulfonium vinyl triflate intermediate A in 93\% yield, which could afford the

Table 5 Scope of other nucleophiles $6^{a b}$

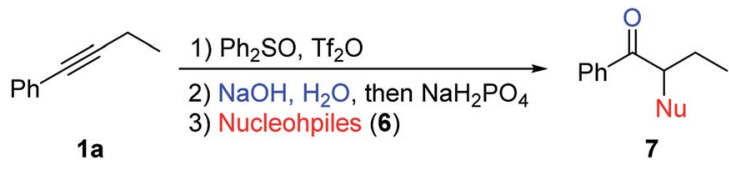<smiles>CCC(Sc1ccccc1)C(=O)c1ccccc1</smiles>

7 aa $72 \%^{c}$<smiles>CCC(Sc1ccccn1)C(=O)c1ccccc1</smiles>

7 ae $84 \%^{c}$<smiles>CCC([As]#N)C(=O)c1ccccc1</smiles>

7aj $73 \%$<smiles>CCC(Sc1ccc([N+](=O)[O-])cc1)C(=O)c1ccccc1</smiles>

7 ab $66 \%{ }^{c}$<smiles>CCC(Sc1ccccc1C)C(=O)c1ccccc1</smiles>

7 ac $67 \%^{c}$<smiles>CCC(SC(C)=O)C(=O)c1ccccc1</smiles>

7af $67 \%$<smiles>CCC(I)C(=O)c1ccccc1</smiles>

7ak $86 \%$<smiles>CCOC(=S)SC(CC)C(=O)c1ccccc1</smiles>

7 ag $84 \%$<smiles>CCC(Br)C(=O)c1ccccc1</smiles>

7al $79 \%$

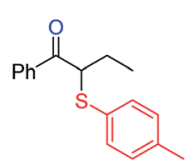

$\operatorname{7ad} 64 \%^{c}$<smiles>CCC(N)C(=O)c1ccccc1</smiles>

7ai $66 \%$<smiles>CCC(O)C(=O)c1ccccc1</smiles>

7 am 64\% ${ }^{d}$
${ }^{a}$ Standard conditions A: (1) $1 \mathrm{a}(0.4 \mathrm{mmol}), \mathrm{Ph}_{2} \mathrm{SO}(0.48 \mathrm{mmol})$, and $\mathrm{Tf}_{2} \mathrm{O}$ $(0.48 \mathrm{mmol}) ;(2) \mathrm{NaOH}(1.2 \mathrm{mmol}), \mathrm{H}_{2} \mathrm{O}(8 \mathrm{mmol})$, and $\mathrm{NaH}_{2} \mathrm{PO}_{4}(0.8$ mmol); (3) 6 (0.6 mmol). ${ }^{b}$ Isolated yield. ${ }^{c}$ The reaction was performed without adding $\mathrm{NaH}_{2} \mathrm{PO}_{4}$ in step 2. ${ }^{d}$ Skipped step 2 and added aqueous $n \mathrm{Bu}_{4} \mathrm{NOH}$ solution as the nucleophile in step 3 .

product 5aa after reacting with potassium acetate and water (Scheme 2a). The attempted hydrolysis of intermediate A with water alone did not occur in this case before the addition of basic potassium acetate. While hydrolysis of intermediate A did occur with sodium hydroxide and water, sulfonium salt $\mathbf{B}$ and

Table 6 Scope of ambident nucleophiles $8^{a b}$

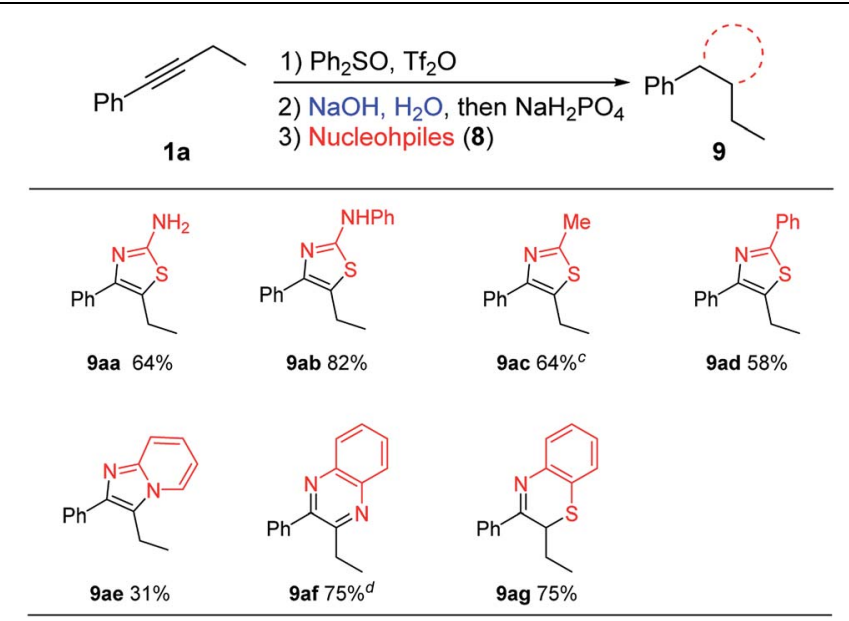

${ }^{a}$ Standard conditions A: (1) $1 \mathrm{a}(0.4 \mathrm{mmol}), \mathrm{Ph}_{2} \mathrm{SO}(0.48 \mathrm{mmol})$, and $\mathrm{Tf}_{2} \mathrm{O}$ $(0.48 \mathrm{mmol}) ;(2) \mathrm{NaOH}(1.2 \mathrm{mmol}), \mathrm{H}_{2} \mathrm{O}(8 \mathrm{mmol})$, and $\mathrm{NaH}_{2} \mathrm{PO}_{4}(0.8$ mmol); (3) 8 (0.6 mmol). ${ }^{b}$ Isolated yield. ${ }^{c}$ Added extra $2 \mathrm{~mL}$ dichloroethane and stirred at $60{ }^{\circ} \mathrm{C}$ in step $3 .{ }^{d}$ Added 3 eq. DDQ after step 3. 


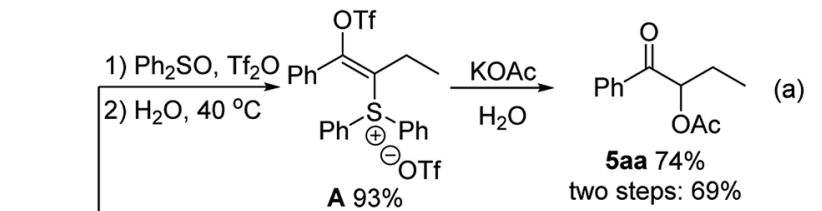

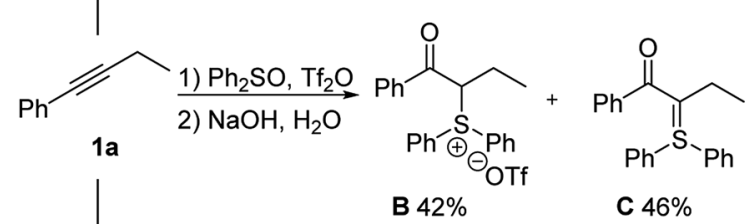

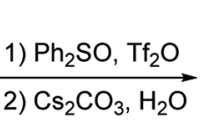

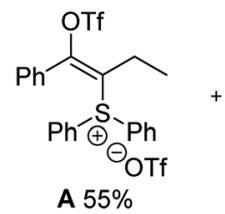<smiles>CCC(C(=O)c1ccccc1)[Pb]([O-])([Pb])[Pb]</smiles>

Scheme 2 Isolation of reaction intermediates.

sulfur ylide $\mathrm{C}$ were isolated in $42 \%$ and $46 \%$ yields, respectively (Scheme 2b). With the weaker base cesium carbonate instead of the stronger base sodium hydroxide, $\alpha$-sulfonium ketone intermediate $\mathbf{B}$ was obtained in $41 \%$ yield in addition to the $55 \%$ yield of sulfonium vinyl triflate $\mathbf{A}$ (Scheme $2 \mathrm{c}$ ). ${ }^{21}$

To further explore the application of this reaction in the context of natural product derivatization, alkyne $\mathbf{1 0}$ was prepared in two steps from estrone (Scheme 3). Our difunctionalization reactions proceeded smoothly, and desired products 11, 12 and 13 were afforded in 55\%, 69\% and 65\% yields (ca. 1:1 mixture of two epimers with the newly generated stereocenters), respectively.

Our preliminary results of a catalytic asymmetric version of this reaction are shown in Scheme 4 . When a chiral PCCP catalyst $^{22}$ was added in step 3 and the reaction temperature lowered to $-20{ }^{\circ} \mathrm{C}, \alpha$-amino ketone 3 ba was obtained in $67 \%$

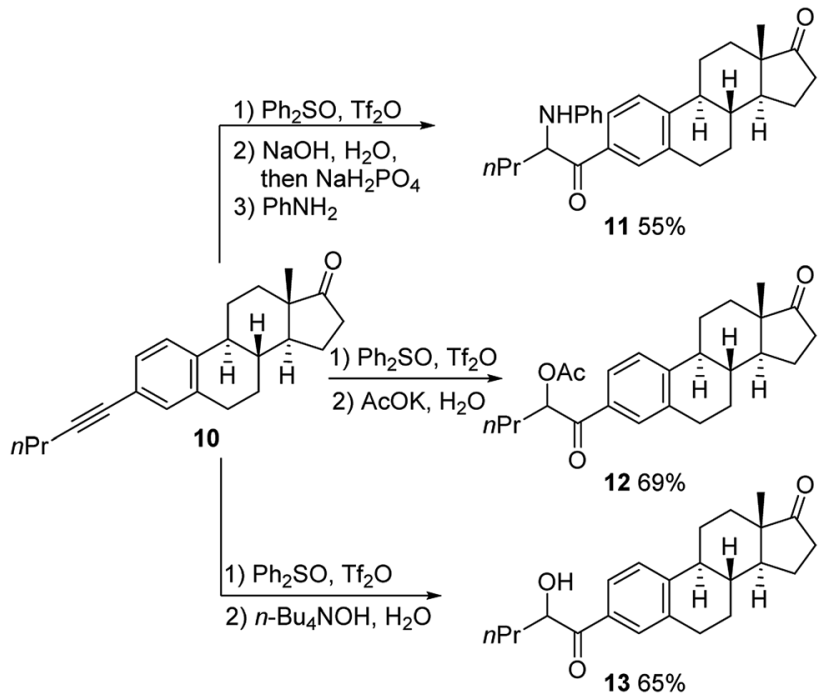

Scheme 3 Functionalization of estrone derivative 10.
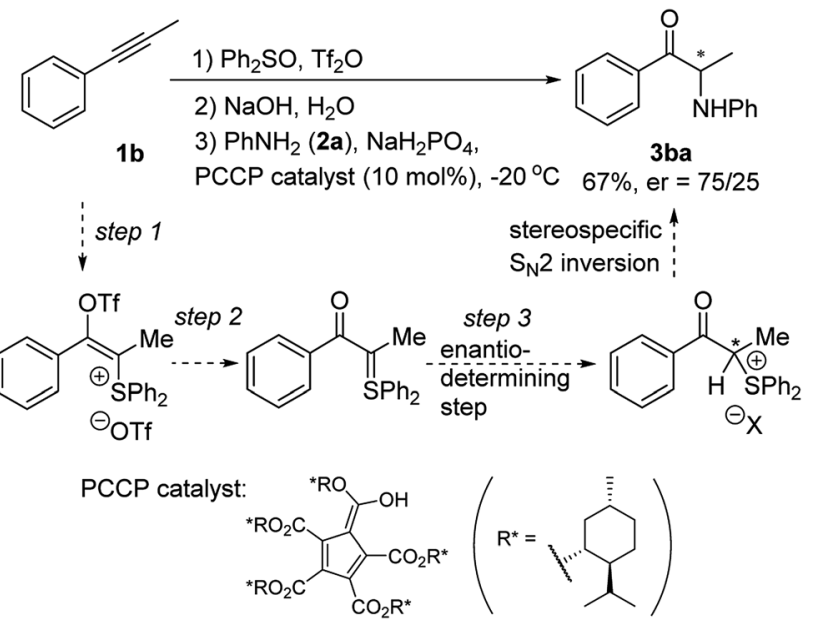

Scheme 4 Preliminary results of a catalytic asymmetric version.

yield and $50 \%$ ee, which indicates the feasibility to develop a chiral Brønsted acid catalyzed reaction to prepare enantioenriched $\alpha$-amino ketones directly from alkynes.

\section{Conclusions}

In conclusion, we have developed a general procedure for the synthesis of $\alpha$-heterosubstituted ketones through sulfur mediated difunctionalization of internal alkynes. A variety of $\alpha$ substituted ketones could be prepared by using nitrogen, oxygen, sulfur and halogen nucleophiles. Applications for the synthesis of heterocycles and derivatization of natural products are also realized. We are currently exploring the catalytic asymmetric version of this reaction, and those results will be reported in due course.

\section{Conflicts of interest}

There are no conflicts to declare.

\section{Acknowledgements}

This research was supported in part by the National Natural Science Foundation of China $(21402005,21572017)$ and the Fundamental Research Funds for the Central Universities (XK1802-6, 12060093063).

\section{Notes and references}

1 Product Class 6: $\alpha$-Heterosubstituted Ketones, in Science of Synthesis, ed. J. Cossy, Georg Thieme Verlag, Stuttgart, 2005, vol. 26.

2 D. M. Perrine, J. T. Ross, S. J. Nervi and R. H. Zimmerman, J. Chem. Educ., 2000, 77, 1479-1480.

3 K. F. Foley and N. V. Cozzi, Drug Dev. Res., 2003, 60, 252-260. 4 (a) B. Maji and H. Yamamoto, Bull. Chem. Soc. Jpn., 2015, 88, 753-762; (b) E. Erdik, Tetrahedron, 2004, 60, 8747-8782; (c) J. M. Janey, Angew. Chem., Int. Ed., 2005, 44, 4292-4300; (d) 
A. M. R. Smith and K. K. Hii, Chem. Rev., 2011, 111, 16371656; (e) D. Sandoval, C. P. Frazier, A. Bugarin and J. Read de Alaniz, J. Am. Chem. Soc., 2012, 134, 18948-18951; (f) P. Selig, Angew. Chem., Int. Ed., 2013, 52, 7080-7082; $(g)$ F. Zhou, F.-M. Liao, J.-S. Yu and J. Zhou, Synthesis, 2014, 46, 2983-3003.

5 (a) L. E. Fisher and J. M. Muchowski, Org. Prep. Proced. Int., 1990, 22, 399-484; (b) P. A. Levene and A. Walti, Org. Synth. Coll. Vol. II, 1943, 2, 5.

6 (a) R. N. Reddi, P. V. Malekar and A. Sudalai, Org. Biomol. Chem., 2013, 11, 6477-6482; (b) R. N. Reddi, P. K. Prasad and A. Sudalai, Org. Lett., 2014, 16, 5674-5677; (c) K. Muñiz, C. H. Hövelmann, A. Villar, R. Vicente, J. Streuff and M. Nieger, J. Mol. Catal. A: Chem., 2006, 251, 277-285; (d) P. K. Prasad, R. N. Reddi and A. Sudalai, Org. Lett., 2016, 18, 500-503; (e) M. H. Shinde and U. A. Kshirsagar, Org. Biomol. Chem., 2016, 14, 858-861; (f) M. Venkat Ram Reddy, R. Kumareswaran and Y. D. Vankar, Tetrahedron Lett., 1995, 36, 6751-6754; (g) A. Villar, C. H. Hövelmann, M. Nieger and K. Muñiz, Chem. Commun., 2005, 0, 33043306.

7 For bormohydration of alkynes see: (a) K. K. Rajbongshi, D. Hazarika and P. Phukan, Tetrahedron, 2016, 72, 41514158; (b) C. Wu, X. Xin, Z.-M. Fu, L.-Y. Xie, K.-J. Liu, Z. Wang, W. Li, Z.-H. Yuan and W.-M. He, Green Chem., 2017, 19, 1983-1989; (c) W. He, L. Xie, Y. Xu, J. Xiang and L. Zhang, Org. Biomol. Chem., 2012, 10, 3168-3171.

8 T. Miura, T. Biyajima, T. Fujii and M. Murakami, J. Am. Chem. Soc., 2012, 134, 194-196.

9 M. Li, L. Zhang, B. Zhao and F. Liang, RSC Adv., 2016, 6, 93325-93329.

10 (a) D.-L. Mo, L.-X. Dai and X.-L. Hou, Tetrahedron Lett., 2009, 50, 5578-5581; (b) G. Deng and J. Luo, Tetrahedron, 2013, 69, 5937-5944.

11 K. Ji, Y. Zhao and L. Zhang, Angew. Chem., Int. Ed., 2013, 52, 6508-6512.

12 For carbohydration of alkynes see: (a) D. Kaiser, L. F. Veiros and N. Maulide, Chem.-Eur. J., 2016, 22, 4727-4732; (b) T. Stopka, M. Niggemann and N. Maulide, Angew. Chem., Int. Ed., 2017, 56, 13270-13274.
13 (a) N. Momiyama and H. Yamamoto, J. Am. Chem. Soc., 2003, 125, 6038-6039; (b) N. Momiyama and H. Yamamoto, J. Am. Chem. Soc., 2004, 126, 5360-5361.

14 R. W. Evans, J. R. Zbieg, S. Zhu, W. Li and D. W. C. MacMillan, J. Am. Chem. Soc., 2013, 135, 1607416077.

15 Z. T. He and J. F. Hartwig, Nat. Chem., 2019, 11, 177-183.

16 (a) G. Hu, J. Xu and P. Li, Org. Lett., 2014, 16, 6036-6039; (b) Z. Zhang, H. Du, J. Xu and P. Li, Chem. Commun., 2016, 52, 11547-11550.

17 (a) G. Hu, J. Xu and P. Li, Org. Chem. Front., 2018, 5, 21672170; (b) Z. Zhang, P. He, H. Du, J. Xu and P. Li, J. Org. Chem., 2019, 84, 4517-4524.

18 (a) L. H. S. Smith, S. C. Coote, H. F. Sneddon and D. J. Procter, Angew. Chem., Int. Ed., 2010, 49, 5832-5844; (b) A. P. Pulis and D. J. Procter, Angew. Chem., Int. Ed., 2016, 55, 9842-9860; (c) A. Shafir, Tetrahedron Lett., 2016, 57, 2673-2682; (d) H. Yorimitsu, Chem. Rec., 2017, 17, 1156-1167; (e) T. Yanagi, K. Nogi and H. Yorimitsu, Tetrahedron Lett., 2018, 59, 2951-2959; ( $f$ ) L. Meng, J. Zeng and Q. Wan, Synlett, 2018, 29, 148-156; (g) Z.-Y. Tian, Y.-T. Hu, H.-B. Teng and C.-P. Zhang, Tetrahedron Lett., 2018, 59, 299-309; (h) V. G. Nenajdenko, P. V. Vertelezkij and E. S. Balenkova, Synthesis, 1997, 1997, 351-355; (i) A. J. Eberhart and D. J. Procter, Angew. Chem., Int. Ed., 2013, 52, 4008-4011; (j) J. A. Fernández-Salas, A. J. Eberhart and D. J. Procter, J. Am. Chem. Soc., 2016, 138, 790-793.

19 Note: diphenyl sulfide was obtained as the byproduct.

20 H. Kobayashi, J. A. Eickhoff and A. Zakarian, J. Org. Chem., 2015, 80, 9989-9999.

21 R. M. P. Dias and A. C. B. Burtoloso, Org. Lett., 2016, 18, 3034-3037.

22 (a) C. D. Gheewala, B. E. Collins and T. H. Lambert, Science, 2016, 351, 961-965; (b) C. D. Gheewala, J. S. Hirschi, W.-H. Lee, D. W. Paley, M. J. Vetticatt and T. H. Lambert, J. Am. Chem. Soc., 2018, 140, 3523-3527; (c) C. Yuan, J. Li and P. Li, ACS Omega, 2018, 3, 6820-6826. 